\title{
DINAMIKA KONTESTASI LEMBAGA ZAKAT DI KOTA MAKASSAR (STUDI DI BAZNAS DAN LAZNAS WAHDAH)
}

\author{
USLUDDIN,HASBI \\ Sekolah Pasca Sarjana \\ Universitas Hasanuddin \\ Email : almandariusluddin@gmail.com, hasbiukm@yahoo.com
}

\begin{abstract}
:
The presence of many zakat institutions in managing zakat, infaq and sadaqah nowadays is a fascinating thing. The zakat institution officially owned by the government of Makassar City which has succeeded in becoming a channel for distributing zakat especially ASN. However the presence of the other zakat institutions seemed to be an arena of contestation to win muzakki, which one of that was LAZNAS Wahdah Makassar, in which relying on the strength of their cadre networking. This research is qualitative field research with descriptiveanalysis method. The conclusion of the research about the contestation dynamics of zakat institutions in Makassar City (Studied at BAZNAS and LAZNAS Makassar City, is namely (1) the dynamics of the miscoordination contestation especially BAZNAS vs LAZNAS and (2) the dynamics of reconciliation contestation especially LAZNAS vs. LAZNAS. In this study also revealed the factors that encourage muzakki in distributing zakat, namely: (1) Structural Factors and (2) Cadre Networking Factors. In addition, the efforts to avoid potential conflicts of contestation in zakat institution can be accomplished in 3 ways (1)zoning of the performance of zakat institution (2) develops the program Strategy Plan, and (3) Internal Improvement of zakat institutions
\end{abstract}

Keywords : Contestation, zakat institutions, BAZNAS, LAZNAS Wahdah

\section{PENDAHULUAN}

Sebagai agama akhir zaman, Islam tidak hanya menawarkan satu pola interaksi antara manusia dengan sang Pencipta (Tauhid Ubudiyah). Tapi juga menghendaki adanya ruang dialektis dalam masyarakat, khususnya dimensi ekonomi untuk menciptakan keadilan yang harus tetap tegak untuk menjaga keberlangsungan manusia ${ }^{1}$. Meski begitu ruang dialektis tidak seperti yang dipersepsikan oleh sistem kapitalisme Immanuel Wallerstein, menyatakan ada tiga kecenderungan perkembangan ekonomi dunia kapitalis yaitu berkembangnya produksi mekanisasi, meningkatnya komodifikasi faktor produksi dan berkembangnya proletarianisasi buruh.$^{2}$

${ }^{1}$ Q.S Ali Imran 5:112

${ }^{2}$ Sanderson, Stephen K. 2011. Makrososiologi: Sebuah Pendekatan Terhadap Realitas Sosiologi 2011: 195 
Namun bukan berarti Islam kaku dalam hal kepemilikan aset, seperti paham sosialisme yang sangat jauh mencampuri urusan privat warganya. Dalam batas-batas tertentu, Islam sudah menggariskan berbagai konsep dan aturan penjelasan lainnya guna menghindari eskalasi konflik horizontal. Disinilah peran nabi dan rasul, menjadi pemilik otoritas dalam menafsirkan setiap wahyu yang turun sebagai respon atas latar setting sosial budaya (Asbab al-Nuzul maupun asbab al-wurud).

Zakat merupakan salah satu aspek peribadatan yang secara ketat diatur dalam Islam, mulai dari hulu sampai hilir semua memiliki alur mekanisme yang jelas (QS. At-Taubah ayat 34,60 dan 103 serta QS. Az-Dzariat 19). ${ }^{3}$ Selain dalam al-Quran, hadist Rasulullah juga banyak menyinggung dasar hukum zakat sebagai sebuah ritual ibadah sebagai referensi fundamental kaum muslimin yang kevalidannya sudah tidak diragukan lagi.

BAZNAS merupakan lembaga pemegang otoritatif yang mengurusi persoalan zakat. Status dan kedudukannya legal dibawah komando pemerintah melalui Kementerian Agama Republik Indonesia (Kemenag RI). Namun, masyarakat juga diberikan kebebasan untuk membentuk lembaga serupa untuk untuk tujuan dan maksud yang serupa pula. Lembaga pengelola zakat bentukan masyarakat, inilah yang disebut Lembaga Amil Zakat (LAZ).

Faktanya kehadiran lembaga penghimpun ZIS yang diiniasi oleh organisasi masyarakat (LAZ), harus diakui telah menjelma menjadi satu arena persaingan. Relasi kuasa dan dilema eksalasi potensi konflik menjadi aspek penting dan substantif, agar tidak menjurus pada konflik horizontal dalam masyarakat oleh institusi tersebut.

Relasi kuasa dalam konsep ini sejalan dengan yang diungkapkan oleh Parsons. Kekuasaan merupakan suatu kemampuan untuk menjamin pelaksanaan kewajiban yang mengikat (terhadap tujuan-tujuan kolektif yang telah disepakati) dari satuan-satuan yang ada di dalam satu sistem organisasi kolektif. Dan kalau ada yang berlawanan, maka lembaga yang berkuasa perlu menegakkan sankssanksi situasional yang bersifat negatif (Abdussyani, 2012: 136). ${ }^{4}$

Beberapa hasil penelitian terdahulu telah membahas tentang zakat dalam berbagai perspektif. Misalnya penelitian yang dilakukan oleh ${ }^{5}$ Kuasa Pengetahuan Penelitian yang dilakukan oleh Abdul Malik, dengan judul Konstruksi Sosial Kuasa Pengetahuan Zakat (Studi Kasus Tiga Lembaga Zakat di Provinsi Jambi

${ }^{3}$ QS. At-Taubah ayat 34,60 dan 103 serta QS. Az-Dzariat 19

${ }^{4}$ Abdussayni, (2012). Sosiologi: Skematika, Teori dan Terapan. Jakarta: PT. Bumi Aksara

${ }^{5}$ Malik, Abdul. 2010. Konstruksi Atas Kuasa Pengetahuan Atas Zakat, Disertasi. Bogor: IPB. 
dan Sumatera Barat). Hasil penelitian ini menunjukkan bahwa konstruksi pengetahuan zakat yang terbangun pada tiga model lembaga tata kelola zakat yang diteliti, merupakan hasil dari persentuhan pengetahuan agama, pengetahuan lokal dan sain modern (politik dan ekonomi). Pada Lembaga Amil Zakat (LAZ) komunitas, ditemukan bahwa pertemuan pengetahuan agama dan pengetahuan lokal (local knowledge) menunjukkan adanya dominasi pengetahuan agama. Pada Badan Amil Zakat Daerah (Bazda) ditemukan terjadi pertemuan pengetahuan agama dan sain politik modern dan menunjukkan adanya dominasi sain politik modern. Sementara pada Lembaga Amil Zakat (LAZ) Swasta ditemukan pertemuan pengetahuan agama dan sain ekonomi modern dan menunjukkan adanya dominasi sain ekonomi modern.

Ada pula Penelitian yang dilakukan oleh Hafidz Arfandi dengan judul Wajah Filantropi Indonesia (Studi Komparatif Aktivisme Sosial dan Pendayagunaan Filantropi Islam dalam Upaya Mewujudkan Kesejahteraan Sosial pada Muhammadiyah dan Dompet Dhuafa). Hasil penelitian menunjukkan kedua lembaga ini melahirkan motif yang berbeda. Muhammadiyah cenderung bermotif authority rangking atau menciptakan patronase dengan mengandalkan anggotanya. Sedangkan Dompet Dhuafa lebih cenderung bermotif community sharing dengan mendorong sentimen sosial keumatan ditengah pertumbuhan komunitas menengah muslim.

Perbedaan mendasar penelitian ini dengan penlitian sebelumnya adalah penelitian pertama berdasar pada kuasa pengetahun muzakki dan amil dan berzakat. Sedangkan pada penelitian kedua fokus pada corak dan karakter lembaga zakat yang terwakili oleh LAZISMU Muhammadiyah dan Dompet Dhuafa. Sedangkan dalam penelitian ini, peneliti ingin fokus melihat kontestasi kedua lembaga zakat dalam mendapatkan dan mempertahakn muzakki serta upaya untuk mencegah potensi konflik antara lembaga zakat dimasa mendatang.

Peneliti ingin mengangkat 3 rumusan masalah yang penelitian antara lain (1) Bagaimana konstestasi lembaga zakat (2) Faktor-faktor apa yang menyebabkan muzakki dalam memilih lembaga zakat dan (3) Bagaimana upaya dalam meredam potensi konflik lembaga zakat dimasa mendatang?

\section{PEMBAHASAN}

\section{Lembaga Zakat di Kota Makassar}

Perubahan mendasar pada kedua undang-undang ini terletak pada satus dan peran lembaga zakat yang diinisiasi oleh masyarakat (LAZ). Selain itu, terdapat pula perbedaan pengistilahan yang saat itu masih menggunakan term BAZ. Baik BAZ dan LAZ memiliki peran yang relatif sama dalam mengumpulkan, mengelolah dan mendayagunakan dana zakat, infaq dan sedekah 
di masyarakat. Revisi UU No. 33 Tahun 1999 ini juga membawa perubahan mendasar seperti term BAZ yang diganti menjadi BAZNAS serta pembatasan peran LAZ menjadi pembantu BAZNAS dalam pengelolaan zakat (lihat pasal 23 UU No, 23 Tahun 2011).

BAZNAS Kota Makassar merupakan lembaga resmi dan satu-satunya yang dibentuk oleh pemerintah di Kota Makassar yang pengurusnya (unsur pimpinan) diangkat oleh Walikota Makassar dengan nomor: 1762/451.12/KP/XII/2015 yang memiliki tugas dan fungsi untuk menghimpun dan menyalurkan zakat, infaq dan sedekah (ZIS) pada tingkat Kota Makassar.

Dengan demikian BAZNAS Kota Makassar bersama pemerintah Kota Makassar bertanggungjawab untuk mengawal pengelolaan zakat yang berazaskan syariah islam, amanah, kemanfaatan, keadilan, kepastian hukum, terintegrasi dan akuntabilitas.

Berdasarkan pada UU tersebut, pemerintah mewadahi inisiatif pengelolaan zakat yang berbentuk lembaga zakat. Inilah cikal bakal berdirinya LAZNAS Wahdah Kota Makassar. LAZNAS Wahdah adalah lembaga amil zakat, infak dan sedeqah yang telah menyambung keberkahan antara muzakki (donatur) dan mustahik (penerima manfaat) sejak tahun 2002. Pernyataan legalitas LAZIS Wahdah dibuktikan dengan surat keterangan terdaftar pada Direktur Jenderal Politik dan Pemerintahan Umum Kementerian Dalam Negeri Nomor: 01-0000/21/DIV.1/I/2016. Selain itu juga memiliki surat rekomendasi pendirian lembaga dari Badan Amil Zakat Nasional Nomor 189/HVR/BAZNAS/II/2019.

\section{Dinamika Kontestasi Lembaga Zakat}

Lahirnya lembaga zakat (LAZ) yang diinisiasi oleh masyarakat tampak menjadi peluang sekaligus tantangan bagi BAZNAS. Menjadi peluang, sebab hadirnya LAZ terbukti semakin menyemarakkan dinamika pengelolaan dana zakat dimasyarakat secara profesional. Pun demikian, sekaligus menantang pihak BAZ agar meningkatkan daya saingnya agar tidak ketinggalan dengan ritme yang ada pada LAZ.

Secara istilah, kontestasi bisa dimaknai sebuah upaya perlombaan dalam sebuah ajang agar memenangkan gelar terbaik mengungguli kontestan lainnya. Kontestasi juga menyiratkan banyak hal seperti pergumulan strategi, taktik, target pencapaian, indikator keberhasilan maupun seperangkat ide dan gagasan untuk mencapai tujuan yang hendak dicapai.

Kontestasi lembaga zakat seperti yang terjadi saat ini juga sesuai dengan pinsip untuk saling berlomba dalam kebaikan seperti yang disebutkan dalam Q. S Al-Baqarah ayat 148: 
"Dan setiap umat memiliki kiblat yang dia menghadap kepadanya. Maka berlomba-lombalah kamu dalam kebaikan. Dimana saja kamu berada pasti Allah mengumpulkan kamu semuanya. Sungguh Allah maha kuasa atas segala sesuatu”

Hadirnya banyak lembaga zakat juga mengindikasikan adanya wadah yang bervariasi untuk menunaikan kewajiban zakat kepada muzakki, maupun kaum muslimimn secara umum. Artinya lembaga zakat akan membantu pemerintah dalam melakukan kegiatan literasi seputaran zakat dan hal-hal yang menyangkut dengannya dalam masyarakat. Pemerintah pun akan terbantu dalam rangka melakukan akselerasi pembangunan pembangunan yang bertump pada kolekifisme masyarakat dalam spirit zakat.

Dr. Yusuf Qardhawi, merupakan tokoh intelektual Islam abad 20 berkebangsaan Mesir yang telah menasbihkan dirinya untuk menggeluti pengkajian zakat secara paripurna. Rujukan kitab klasik dengan pembahasan yang sangat baik, beliaulah penulisnya. Dalam salah satu tulisannya beliau berkomentar tentang disyariatkannya zakat:

"Saya tidak dapat memikirkan, bagaimana kehidupan sosial kemasyarakat jika Allah tidak menurunkan syariat seperti yang terkandung dalam zakat. Zakat, selain memiliki ikatan ketauhidan juga sarat dengan nilai kemanusiaan”.

Pertumbuhan jumlah penduduk yang diikuti dengan peningkatan ekonomi masyarakat kelas menengah kaum muslimin, menjadi peluang yang sangat baik demi memaksimalkan akumulasi dana zakat dalam masyarakat. Fakta ini menjadi penyebab bertumbuhnya lembaga zakat, khususnya yang digalang oleh masyarakat.

Ahsin Wijaya menyebut indikasi kontestasi dalam umat Islam akhir-akhir semakin bergejolak. ${ }^{6}$ Bersamaan dengan itu, Kuntowijoyo menambahkan bahwa arena kontestasi pun semakin bervariasi mulai dari aspek sosial, budaya, pendidikan hingga politik. Dari sekian banyak varian kontestasi, bidang politiklah yang paling menunjukkan pola kontestasi yang semakin berdinamika. ${ }^{7}$

Rupa kontestasi yang melibatkan berbagai lembaga zakat juga tidak terlepas dari esensi ajaran Islam itu sendiri. Muhammad Iqbal dalam Reconstruction of Religious Though in Islam menyebut Islam sebagai agama amal. ${ }^{8}$ Agama amal yang dimaksud adalah banyaknya anjuran dalam Islam yang

${ }^{6}$ Wijaya, Aksan. 2019. Kontestasi Merebut Kebenaran Islam di Indonesia: Dari Berislam Secara Teologis Menuju Berislam Secara Humanis. Yogyakarta: IRCiSoD.

${ }^{7}$ Kuntowijoyo. 2018. Identitas Politik Umat Islam. Yogyakarta: IRCiSoD h 107

${ }^{8}$ Kuntowijoyo. 2018. Identitas Politik Umat Islam. Yogyakarta: IRCiSoD h 18 
secara tekstual memberikan perintah untuk berbuat dan beramal saleh dengan orang lain sebagai manifestasi keimanan. Islam tidak hanya dipahami sebagai kumpulan dogma dan hal-hal pengetahuan lainnya. Namun secara faktual, dibuktikan dalam kewajiban zakat, infak dan sedeqah.

Seperti yang telah dijelaskan sebelumnya, bahwa kontestasi juga berarti perspektif lembaga dalam menjalin hubungan koordinasi antar sesama lembaga demi terwujudnya pola pendistribusian dan pendayagunaan zakat sesuai dengan yang diatur dalam hukum negara maupun hukum syariat agama. Kedua lembaga zakat dalam penelitian ini memiliki perpektif yang berbeda dalam melihat kontestasi, selengkapnya akan diuraikan pada penjelasan berikut ini.

\section{Miskoordinasi (BAZ vs LAZ)}

Perbedaan latar belakang lembaga ternyata berdampak signifikan dalam melihat kontestasi yang ada di lapangan. Disadari atau tidak, perbedaan cara pandang ini akan berefek (langsung maupun tidak langsung) pada efektiftas program sebagai bentuk tindak lanjut pendistribusian zakat kepada mustahik. Berikut ini wawancara dengan AZK, salah satu komisioner BAZNAS Kota Makassar:

Antara pembantu dan yang dibantu harus saling sinergi, kalau pembantu salah mudah-mudahan yang dibantu tidak terseretseret. Kalau selama ini tidak pernah koordinasi bagaimana caranya. Kalau tidak salah tapi itu dari LAZ (FOZ). Itu forum mereka. Harusnya yang melakukan inisiatif pertemuan harusnya yang mengeluakan rekomendasi harus melakukan evaluasi. Kalau dalam hal mekanisme proses, harusnya konsolidasi itu dilakukan yang mengeluarkan rekomendasi pembentukan LAZ dari awal. Itu kan kewenangan Kanwil Kemenag Provinsi kenapa saya katakan begitu, kan yang mengeluarkan rekomendasi kan mereka. (Wawancara, 17 November 2019).

Forum Organisasi Zakat (FOZ) merupakan satu-satunya lembaga koordinasi antar pengelola zakat yang ada di Indonesia. Meski keberadaannya bersifat semi formal, tapi efeknya dilapangan sangat terasa khususnya sebagai bentuk koordinasi agar program lebih tepat sasaran. Bersifat semi formal karena pemerintah belum memberikan legalitas resmi terkait adanya forum ini.

BAZNAS Kota Makassar masih sangat dikotomis melihat adanya FOZ sebagai jalan tengah yang melibatkan antar lembaga zakat untuk melakukan koordinasi. Pada wawancara diatas sangat jelas asumsi yang mereka miliki bahwa FOZ merupakan hanya milik LAZ, dan sudah pasti tidak wajib untuk mereka 
berkecimpung di dalamnya.

Hal ini diperkuat pula dengan hasil wawancara dengan Pak H. RA, salah satu pejabat berwenang di Kemenag Provinsi Sulawesi Selatan:

BAZNAS tidak masuk dalam FOZ, karena BAZNAS itu kan lembaga milik pemerintah dan mandiri kecuali dengan kita dalam bentuk koordinasi. Harusnya bertanggungjawab ke kita. Antara BAZ dan LAZ, ada koordinasi pasti ada dalam hal pendistribusian pasti ada. (Wawancara 30 Desember 2019).

Sebab dikotomis itulah sehingga menganggap apa yang dilakukan oleh LAZ yang untuk membentuk sebuah wadah koordinasi telah menyalahi fungsi. Idealnya langkah ini dilakukan oleh Kakanwil Kementerian Agama Provinsi selaku pemberi rekomendasi sejak awal para LAZ itu dibentuk. Lebih lanjut, BAZNAS Kota Makassar berdalih bahwa jika sejak awal Kemenag yang memberi rekomendasi maka itu pula yang harus melakukan supervisi terhadap LAZ termasuk membetuk forum koordinasi yang rutin dilaksanakan.

Hal ini justru bertolakbelakang dengan hasil wawancara dengan Pak H. RA, salah satu pejabat berwenang di Kemenag Provinsi Sulawesi Selatan:

Tidak, kami tidak campuri FOZ yang penting tidak mencampuri masing-masing LAZ yang penting mustahik yang satu tidak digarap lagi oleh LAZ yang lain. Kemenag hanya bersifat koordinasi dengan monitoring. Tergantung anggaran, kalau ada kita adakan. Tapi umumnya mereka akan melapor ke kita terkait program dan pendistribusian zakat. Dengan begitu kompetisi tidak ada.(Wawancara, 30 Desember 2019)

Dari wawancara di atas dapat disimpulkan bahwa forum koordinasi yang sedianya diwadahi oleh Kemenag justru bersifat tentatif mengikuti kesiapan anggaran. Padahal idealnya forum koordinasi dapat dilaksanakan oleh secara simultan dan berkelanjutan sehingga upaya monitoring dan evaluasi lembaga dapat dilaksanakan dengan baik dan efektif.

Hasil akhir perbedaan inilah yang membuat dinamika kontestasi antar lembaga zakat menjadi hubungan miskoordinasi, baik dalam hal pengumpulan maupun pendayagunaan zakat. Miskoordinasi mengindikasikan sebuah perbedaan dan potensi tumpang tindih mustahik. Meski demikian bukan berarti bahwa kedua lembaga tidak memiliki hubungan komunikasi sama sekali. Pada kasus-kasus tertentu, ada koordinasi yang terjalin di antara mereka.

\section{Dinamika Rekonsiliasi (LAZ vs LAZ)}

Rekonsiliasi dapat dipahami sebagai sebuah proses yang melibatkan adanya hubungan kerja sama, saling mendukung, saling membantu guna memenuhi target yang telah ditentukan meskipun dua lembaga yang berbeda. Biasanya rekonsiliasi ditempuh jika ada masalah yang sama dihadapi oleh dua 
lembaga dua lembaga yang berbeda. Berikut ini petikan wawancara dengan Ust. SA, selaku staff operasional LAZNAS Wahdah:

Adanya BAZNAS dan LAZNAS yang lain bukan batu sandungan. Malah kita saling memotivasi Misalnya dengan BMH kita studi banding, mereka open sangat data bahkan mereka memberikan trik dan caranya. Karena secara pengalaman, mereka peringkat 1. Antar lembaga zakat saling membuka data, kadang kami ke kantornya. Sesama LAZ, kami saling support. Tapi dengan BAZ, hanya sekedar sharing program. Adapun BAZ dan LAZ tidak terlalu, logikanya jika kita satu rumah lebih mudah akrab dibanding yang di luar rumah.(Wawancara, 18 November 2019)

LAZIS Wahdah cenderung lebih terbuka dengan sesama LAZ lainnya. Hal ini diakibatkan karena status kelembagaan yang memiliki banyak kesamaan sehingga mendorong mereka untuk saling terbuka satu sama lain. Lebih jauh, ruang komunikasi sudah telah berlanjut ke tahap branchmarking agar antar lembaga zakat dapat saling berbagi khususnya LAZ yang sudah memiliki reputasi dan pengalaman panjang di bidang zakat.

Menggunakan istilah antar LAZ sebagai gambaran satu rumah yang sama, memberikan pemahaman bahwa hubungan emosional sangat dekat dan terbangun sejak awal. Dengan kata lain, LAZIS Wahdah masih diskriminatif menanggapi perbedaan status kelembagaan BAZNAS sebagai lembaga resmi pemerintah dibandingkan sesama LAZ.

Hal yang sama juga diungkapkan oleh Pak SY, selaku direktur LAZIS Wahdah:

Adanya banyak lembaga zakat secara otomatis munculnya persaingan akan mendorong inovatif dan kreatif dan saya cenderung melihat hal itu juga karena potensi pasar sangat besar dan tidak cukup hanya jika dimonopoli oleh satu lembaga. Berbagai lembaga zakat memiliki kemiripan tapi tetap ada perbedaan, misalnya ciri khas yang orang mudah kenali bagi orang lain. Bagaimana kolaborasi itu adalah membuat menjaga lembaga kita dan fokus di situ.(Wawancara, 18 November 2019)

Harus diakui bahwa hadirnya berbagai lembaga zakat akan memancing daya nalar untuk senatiasa berpikir kreatif dan inovatif. Sebab dengan begitu, program-program yang menjadi andalan lembaga zakat yang ingin disampaikan kepada muzakki dapat dipahami dengan baik, sehingga mempengaruhi sekaligus menarik minat untuk menyalurkan zakatnya. Dapat disimpulkan bahwa lembaga zakat yang mampu memaksimalkan potensi ini, maka merekalah yang bisa eksis dalam dinamika kontestasi yang ada.

LAZIS Wahdah Kota Makassar juga sangat berharap pada ide-ide kreatif dan inovatif dalam menghasilkan program yang menarik. Kemiripan program 
antar lembaga zakat memang sesuatu yang hal tak terhindarkan sebab mustahik sudah dijelaskan dalam Al-Quran, itulah yang disebut sebagai asnab yang berjumlah 8 golongan. Namun yang membedakan diantara mereka adalah kreatifitas dan inovatiflah untuk merumuskan program sesuai dengan kontekstualisasi atas kondisi-kondisi sosial yang terjadi hari ini.

Penekanan istilah potensi pasar yang dimaksud pada wawancara diatas bermakna peluang untuk mendapatkan muzakki secara maksimal. Hal ini menggambarkan betapa optismisnya LAZNAS Wahdah Kota Makassar agar dapat bersaing dengan lembaga zakat yang lain, tak terkecuali dengan BAZNAZ itu sendiri. Sedangkan term konflik (pada kutipan wawancara diatas) lebih kearah perbedaan status lembaga zakat yang berimplikasi pada perbedaan program kerja, perbedaan indikator, dan perbedaan sasaran target.

Menyadari adanya perkembangan dalam pengelolaan lembaga zakat yang semakin maju, LAZIS Wahdah menyadari hal tersebut sehingga selalu terbuka untuk melakukan kolaborasi dengan lembaga lainnya demi menjaga efektifitas program yang lebih baik dimasa mendatang. Prinsip kolaborasi yang terjalin selamanya, biasanya hanya pada aspek pendistribusian dan pendayagunaan zakat. Namun dalam hal pengumpulan, kembali ke lembaga masing-masing.

Kolaborasi antar lembaga selain berdampak langsung pada program, juga dapat meningkatkan silaturahmi sekaligus saling menguatkan. Pada wawancara diatas tergambar jelas kolaborasi tersebut menjadi ajang untuk saling branchmarking guna sharing ilmu dan pengalaman. Bukan hanya terbatas pada aspek kewilayahan, tapi juga dengan lembaga zakat yang ada di Jawa.

\section{Faktor-Faktor Muzakki Dalam Menyalurkan Zakat}

\section{Faktor Struktural}

Peter L Berger merupakan Sosiolog yang melihat konstruksi sosial dalam masyarakat dapat ditemui pada berbagai aspek. Konstruksi sosial yang dimaksud dengan mendasarkan teorinya pada tiga indikator utama yaitu objektivasi, internalisasi dan sosialisasi ${ }^{9}$. Menurutnya, manusia tidak bisa terlepas pada tiga aspek indikator tersebut.

Peran serta pemerintah dalam mengupayakan akselerasi zakat dalam dimensi pembangunan dengan melahirkan berbagai produk legislasi sebagai tata acuan bagi masyarakat dalam berzakat yang berbentuk seperangkat peraturan

${ }^{9}$ Malik, Abdul. 2010. Konstruksi Atas Kuasa Pengetahuan Atas Zakat, Disertasi. Bogor: IPB h 120 
perundang-undangan serta perangkat pendukungnya merupakan upaya objektifikasi oleh pemerintah seperti yang diungkap oleh Berger.

Di level daerah, upaya objektifikasi zakat semakin dikuatkan dengan dikeluarkannya Peraturan Walikota (Perwali) yang menghimbau kepada seluruh Aparatur Sipil Negera untuk menyalurkan zakat infaq dan sedekahnya pada lembaga zakat resmi pemerintah, dalam hal ini BAZNAS Kota Makassar. Tak sampai disitu, pada beberapa OPD (organisasi perangkat daerah) membuatkna nota kesepahaman tentang kerjasama antara BAZNAS Kota Makassar untuk memotong langsung dari gaji ASN yang pada OPD tersebut.

Meski belum berjalan maksimal, tampak Perwali tersebut cukup sukses untuk mendorong ASN untuk menyalurkan zakat infaq maupun sedeqah kepada BAZNAS Kota Makassar. Hal ini tergambar dalam wawancara dengan salah satu Muzakki R:

Yang diakui hanya BAZNAS, melihat lembaga lain di Makassar BAZNAS haruslah membayar zakat disana karena sudah jelasnya milik pemerintah. Boleh-boleh saja karena mungkin UPZ BAZNAS nda ditahu atau nda bayar disitu orang bayar zakat kan boleh-boleh saja. Karena saya PNS dan mayoritas teman-teman BAZNAS karena saya juga UPZ disana dan juga walikota juga menggalakkan untuk bayar zakat di BAZNAS. Memang didukung dengan Perwali. (Wawancara, November 2019)

Hal ini juga dikuatkan wawancara dengan S:

Potongan gaji ji kayaknya. Karena ada daftarnya untuk berzakat di BAZNAS, jadi mengikut saja. Iya, tapi tidak seberapa pun. Saya tidak tahu persis, berapa jumlahnya. Tidak ji pak. Saya juga tidak mengajak karena baru pindah ke kelurahan. Waktu masih di Balaikota, staff PP kan ada daftar. Sudah pindah, kena mutasi. (Wawancara, November 2019)

Wawancara dengan Ibu MY, sebagai berikut:

Ini mungkin yaa yang dipotong setiap bulan. Kalau anu yang dibayar ke panti-panti asuhan, bukan ya...Awalnya gaji masuk ke rekening, ada slip dari bendara kemudian kembalikan lagi ke bendahara baru bendahara yang setor ke BAZNAS. Namun ada juga yang setor sendiri. Utuh dulu baru kemudian potong sendiri.(Wawancara, November 2019)

Adanya pertanyaan pada pembuka dari informan pada wawancara diatas menunjukkan bahwa muzakki belum sepenuhnya mengerti pada apa yang mereka setor setiap bulan ke BAZNAS Kota Makassar.

2. Faktor Jejaring Kader

Pada pembahasan sebelumnya telah dijelaskan bahwa LAZNAS Wahdah masih sangat dominan dipengaruhi oleh kesadaran jejaring kader untuk menjadi 
muzakki maupun donatur tetap. Hal ini tergambar dalam wawancara dengan informan E sebagai berikut:

Karena dulu saya pernah di Wahdah waktu kuliah, saya percaya dengan LAZIS Wahdah, pengurusnya apa semua. Kita pernah sama-sama sejak SMA kader Wahdah. Dulunya itu bernama Wihdatul Ummah. Saya generasi kedua. Sampai kuliah dan sampai saat ini. tapi karena semua sudah kerja, jadi temantemanku yang dulu semua sudah diluar kota. Saya rutin berinfak di LAZIS dan BMH.Jenisnya infaq dan sedekah. (Wawancara, Desember 2019)

Hampir sama dengan kedua informan sebelumnya, wawancara dengan informan $\mathrm{MH}$ :

Karena ikatan emosional karena sering ikut kajian-kajian di masjid Wahdah di DPP Darul Hikmah. Ada juga tarbiyah di BTP bersama teman-teman.Infaq, rutin perbulan. Sekitar 3 tahun. Sudah konsisten, dengan dua lembaga. (Wawancara, Desember 2019)

Pendapat di atas juga didukung dengan hasil wawancara dengan informan lain, dengan AS:

Kalau program semua hampir sama ji, penyaluran pasti mi ke yang membutuhkan tapi lebih bai lagi mungkin saya berpikir bahwa kalau memang kita itu orang ikhlas harus ada organisasi atau persatuan karena saya punya anak juga sekolah disitu saya juga biasa ikut "pengajiannya" jadi sekalian mi. karena bagaimana pun juga persatuan harus diperkuat, meskipun kita tidak taklid disitu. Saya tarbiyah juga di sana.

Juga dikuatkan dengan hasil wawancara dengan

Memilih LAZIS Wahdah karena memang kader, tahun berapa yah, sejak menjadi anggota WI sejak 2010. Kan sudah sreg (cocok, peneliti) to, insya Allah tidak (pindah-pindahmi, peneliti) mi. (Wawancara, November 2019)

Informan WW merupakan ASN Kota Makassar yang mengajar pada sekolah di Makassar, ternyata Perwali yang menghimbau ASN untuk berzakat ke BAZNAS Kota Makassar ternyata tidak menjadi alasan bagi WW untuk menyalurkan zakatnya. Hal ini mengindikasikan bahwa jejaring justru kader justru lebih kuat mempengaruhi informan untuk berzakat. Bahkan bukan hanya zakat profesi, tapi juga fitrah pun tetap di salurkan di LAZNAS Wahdah.

Hal ini juga diakui oleh informan Z:

Kalau ke LAZIS sejak tahun lalu (2019, peneliti), kalau di pengajian tarbiyah saya sudah 4 tahun kan ada juga sumbangan untuk infaq di pengajian. Infaq dan sedeqah, sama yang Ramadhan juga. Ada juga 
celengannya to, terus via transfer juga. Kalau zakat fitrah, tetap di masjid karena orang tua juga amil. Saya juga promosi, itu celengannya saya taruh di ruangan kalau ada teman-teman mau infaq. Kalau ada majalah saya kasi teman juga untuk dibaca-baca, siapa tau tertarik.(Wawancara, desember 2019)

Meski orang tua $\mathrm{Z}$ mrupakan amil pada lembaga zakat milik pemerintah, juga tidak mempengaruhi untuk menyalurkan infak dan sedekahnya ke lembaga tersebut. LAZIS Wahdah menjadi pilihan karena memang sudah menjalani rutinitas tarbiyah selama ini.

\section{Upaya Pencegahan Potensi Konflik Lembaga Zakat}

1. Pewilayahan kinerja lembaga zakat

Hadirnya dua jenis lembaga zakat (pemerintah dan swasta) memang ditengarai akan berefek pada beberapa kondisi. Hal ini juga terungkap dengan wawancara dengan salah satu informan ahli Dr. Abdul Hamid Habbe (Dosen dan Praktisi Ekonomi Islam) seperti dalam wawancara beitkut ini:

Angkat saja BAZNAS sebagai holding, dia mengkoordinir biarkan dia (LAZ-LAZ, peneliti) itu sebagai cabang yang mandiri tapi holdingnya di BAZNAS itu sebagai pengontrol. Karena ada potensi LAZ yang berbasis ormas ada kemungkinan masalah dalam alokasi dana zakat ke mereka juga. Nah dengan holding dapat mengatur wilayah kerja masing-masing LAZ. Itu lebih efektif, kontrol dan koordinasi jauh lebih baik. (Wawancara, November 2019).

Salah satu solusi untuk mewujudkan lembaga zakat dimasa mendatang dengan mengubah status BAZNAS menjadi holding yang membawahi semua lembaga zakat swasta. Diyakini bahwa sistem holding akan meningkatkan jalur koordinasi dan supervisi, dibanding yang sudah ada selama ini. Jika pengelolaan zakat berbentuk holding, maka efektifitas pengelolaan akan semakin kompetitif layaknya operasionalisasi dalam dunia korporasi.

Sehubungan dengan itu, ada pula pendapat lain tentang mekanisme untuk menghindari tumpang tindih program pada dua mustahik yang berbeda. Seperti yang terungkap dalam wawancara dengan Dr. Shuhufi Muhammad:

Mereka merekrut muzakki secara nasional dan pembagiannya juga secara nasional, misalnya mengambil zakat di Makassar pembagiannya di Papua. Mereka juga harus punya data skala lokal. Makanya ini mi yang biasa bikin orang malas ke LAZNAS.Menggunakan persentase untuk membagi skope program nasional dan lokal. Jangan hanya fokus pada masalah nasional dan internasional hingga melupakan isu-isu lokal yang masih banyak. (Wawancara, November 2019) 
Yusuf Qardhawi juga berpendapat demikian. Menurutnya persoalan penting dalam masalah zakat adalah pengumpulan zakat dari para muzakki dan kemana mesti disalurkan. ${ }^{10}$ Carut marut dalam pendistribusian zakat kepada mustahik tidak akan menjangkau mustahik yang lain, sebab boleh jadi seorang mustahik mendapatkan porsi lebih banyak sedangkan yang lain tidak dapat.

2. Mengembangkan Rencana Strategi Program

Banyaknya program yang diterapkan dalam pengentasan kemiskinan selama ini memang kurang berefek positif. Bahkan kecenderungan menunjukkan hal yang sebaliknya, jika ada program bantuan dalam masyarakat maka unsur ketergantungan yang diakibatkan lebih tinggi daripada unsur pemberdayaan. Padahal pemberdayaan itulah yang menjadi tujuan setiap program itu dikeluarkan.

Hal ini menjadi titik tekan Dr. Shuhufi Muhammad dalam wawancara berikut ini:

Jadi kan sistem penyaluran zakat, ada pada taraf fakir dan miskin. Fakir tidak bisa dibantu modal, bagaimana mau berdaya kalau makan saja belum cukup. Misalnya sudah 5 lima tahun dibantu, secara teori harusnya sudah jadi muzakki. Kalau didamping terus. Tapi karena programnya parsial-parsial, akhirnya kontrol terhadap mustahik tidak ada. Jadi 5 tahun berikutnya, paling tidak $20 \%$ harus naik kelas jadi muzakki. (Wawancara, November 2019)

Jika pembinaan mustahik dalam dilakukan oleh lembaga zakat sebagai satu mekanisme proses yang penting dilakukan, maka metaforfosis dari mustahik menjadi muzakki sangat dimungkinkan terjadi. Selain itu, kontrol mustahik ini juga menjadi poin penting agar program tidak menjadi perangkat kemiskinan baru dan turun-temurun di masyarakat. Jika bisa dilakukan dengan efektif, yang ditunjang dengan berbagai indikator pengukuran maka perubahan mustahik dapat terjadi.

Inilah pola pikir yang paling utama harus disampaikan oleh lembaga zakat kepada para mustahiknya. Hal yang sama juga diakui oleh H. RA:

Saat ini BAZNAS sudah mengembangkan zakat produktif, zakat yang kita berikan untuk menjadikan modal usaha. Harapan jauh kita dari tangan dibawah menjadi tangan diatas. Tentu masih butuh banyak waktu untuk mengubahnya, tapi konsepnya ingin kesana. (wawancara, 31 Desember 2019)

\footnotetext{
${ }^{10}$ Scharf, R Betty. 2004. Sosiologi Agama (Edisi Kedua). Jakarta: Kencana
} 


\section{Perbaikan Internal Lembaga Zakat}

Terciptanya kondisi yang kondusif dan profesional juga salah satu daya tarik untuk meningkatkan kesadaran masyarakat untuk bayar zakat. Sebab daya dorong lembaga juga akan berimbas pada citra sebuah lembaga zakat dalam masyarakat.Wawancara dengan Dr. Shuhufi Muhammad sebagai berikut:

Aturan ini juga lebih memacu BAZNAS agar lebih kreatif, karena kalau tidak akan dikalah oleh LAZ. Apalagi dari segi SDM, teman2 LAZ anak muda semua, jadi programnya bagusbagus. Kalau BAZNAS ya begitu-begitu saja. Sudah bagus karena tidak bisa lagi PNS sebagai komisioner. (Wawancara, November 2019)

Selain itu, kehadiran UPZ yang menjadi badan semi otonom BAZNAS juga harus dapat memainkan fungsi secara efektif untuk dapat menghimpun zakat secara optimal. Seperti dalam wawancara berikut ini:

Harusnya ada pembagian kewajiban antara UPZ dan BAZNAS dalam hal pendistribusian zakat tapi panitia masjid berfikir kemarin sosialisasi sehingga pelanggaran UPZ kalau menyalurkan sepenuhnya tapi akhirnya UPZ malas bekerja karena hanya diberikan sosialisasi ancaman kalau tidak melanggar itu proses pembinaan yang kurang. Tapi kalau masjid di kampung-kampung, masa mereka kumpul baru disetor ke BAZNAS. Artinya dia butuh lebih banyak lagi jamaahnya, kalau jamaahnya rata-rata orang miskin pasti dia habiskan.(Wawancara, November 2019)

Mendorong UPZ untuk naik tingkat menjadi LAZ menjadi satu terobosan baru untuk mengoptimalkan pendayagunaan zakat salah satu yang bisa ditempuh. Selain itu, memberlakukan aturan yang berbeda antara UPZ masjid perkampungan dan perumahan elit. UPZ perumahan mewah sangat mungkin untuk mengubah lembaga menjadi LAZ, sebab pola pikir jamah yang sudah maju dan berkembang sehingga tata kelola kelembagaan bisa ditempuh. Sisa perbaikan manajerial seperti pendataan tentang muzakki dan musyawarah program yang ingin digarap. Jika masjid berjalan seperti ini, maka akan tercipta masjid sebagai satu wadah pemberdayaan bagi masyarakat sekitar.

Hal ini juga dapat mengurangi segregasi antara perumahan mewah dan perkampungan kumuh yang kerap kali disaksikan berdampingan dengan perumahan elit. BAZNAS pun tidak harus memberlakukan tentang porsi kewenangan persentase pembagian UPZ, khususnya UPZ masjid di perumahan mewah dan perkampung biasa. Secara regulasi, UPZ memang diberikan 
kewenangan untuk membagi $70 \%$ dana zakat yang terkumpul sisanya ke BAZNAS Kota/Provinsi serta laporan pendistribusian.

Pada masjid berstatus perkampungan biasa, bisa saja porsi itu cukup karena jumlah asnab zakat yang banyak disekitar masjid. Maka kewenangan untuk mendistribusikan dana zakat yang terkumpul harus diberlakukan, beda dengan UPZ masjid di perumahan elit. Sebab jumlah asnab zakat yang relatif lebih kecil.

Memanfaatkan UPZ untuk tidak berfungsi secara musiman misalnya saat moment-moment tertentu, sebenarnya sudah menjadi perhatian BAZNAS Provinsi Sulsel seperti dalam wawancara berikut ini:

Kita pun sudah merencakan bagaimana UPZ itu dapat maksimal kerjanya, bukan hanya menjelang bulan puasa atau lebaran pi. Ya ini memang arah pengembangan organisasi kedepan bagaimana mendorong zaka untuk pemberdayaan masyarakat. (Wawancara,31 Desember 2019)

\section{SIMPULAN}

Berdasarkan temuan dalam penelitian ini yang telah dipaparkan pada pembahasan sebelumnya, beberapa poin yang menjadi kesimpulan seperti berikut ini:

1. Kontestasi lembaga zakat di Kota Makassar berefek positif, sebab muzakki dimudahkan untuk menyalurkan zakat, infaq maupun sedekah kepada mustahik. Ada 2 bentuk kontestasi yaitu (1) dinamika miskoordinasi (BAZNAS vs LAZNAS) dan (2) dinamika rekonsiliasi (LAZNAS vs LAZNAS).

2. Faktor-faktor yang memperangaruhi muzakki dalam berzakat yaitu (1) faktor strutural dan (2) faktor jejaring kader

3. Ada 3 poin yang menjadi upaya peredam potensi konflik antar lembaga zakat (1) pewilayahan kinerja lembaga zakat, (2) mengembangan strategi rencana program dan (3) perbaikan internal lembaga zakat. Ketika ketiga hal ini bisa dievaluasi, maka zakat akan menunjukkan efektifitas yang lebih baik dimasa mendatang.

\section{DAFTAR PUSTAKA}

Abdussayni, (2012). Sosiologi: Skematika, Teori dan Terapan. Jakarta: PT. Bumi Aksara.

Arfandi, Hafidz. 2017. Wajah Filantropi Indonesia (Studi Komparatif Aktivisme Sosial dan Pendayagunaan Filantropi Islam dalam Upaya Mewujudkan Kesejahteraan Sosial pada Muhammadiyah dan Dompet Dhuafa).

Creswell, John W. 2016. RESEARCH DESIGN, Pendekatan Kualitatif, Kuantitaif, dan Campuran. Yogyakarta: Pustaka Pelajar. 
Damsar \& Indrayani. Pengantar Sosiologi Perkotaan. 2017. Jakarta: Kencana

Fakih, Mansour. 2013. Runtuhnya Teori Pembangunan dan Kebudayaan. Yogyakarta: Pustaka Pelajar

Kuntowijoyo. 2018. Identitas Politik Umat Islam. Yogyakarta: IRCiSoD

Lubis, Akhyar Yusuf. 2014. Postmodernisme: Teori dan Metode. Jakarta:Rajawali Press

Midgey, James. 2005. Pembangunan Sosial: Perspektif Pembangunan dalam Kesejahteraan Sosial. Direktorat Perguruan Tinggi Agama Islam Kementerian Agama RI.

Malik, Abdul. 2010. Konstruksi Atas Kuasa Pengetahuan Atas Zakat, Disertasi. Bogor: IPB.

Purwanto, Wendi. Kontestasi Teks dan Realita Sosial: Sakralitas Amil Zakat di Dusun Nuguk Kab. Melawi Kalimantan Barat. Jurnal Kajian Agama Sosial dan Budaya Vol. 4 No. 1 Juni 2019. UIN Sunan Kalijaga Yogyakarta.

Ritzer, George. 2012. Teori Sosiologi Dari Sosiologi Klasik Sampai Perkembangan Terakhir Posmodern. Yogyakarta: Pustaka Pelajar

Ritzer, George. 2016. Sosiologi Ilmu Pengetahuan Berparadigma Ganda. Cetakan ke 12. Jakarta: PT. Raja Grafindo Persada.

Ritzer, George. 2014. MacDonaldisasi Masyarakat. Cetakan ke 1. Yogyakarta: PT. Pustaka Pelajar.

Sanderson, Stephen K. 2011. Makrososiologi: Sebuah Pendekatan Terhadap Realitas Sosiologi Edisi Kedua. Jakarta: Rajawali Press.

Scharf, R Betty. 2004. Sosiologi Agama (Edisi Kedua). Jakarta: Kencana

Sugiyono. 2014. Metode Penelitain Kuantitatif, Kualitatif, dan R\&D. Bandung: ALFABETA, CV.

Susilo, Rachmad K Dwi. 2008. 20 Tokoh Sosiologi Modern. Yogyakarta: Arruz Media

Widyawati. 2011. Filantropi Islam dan Kebijakan Negara Pasca Orde Baru: Studi Tentang Undang-Undang Zakat dan Undang-Undang Waqaf. Bandung: Arsad Press. 
Wijaya, Aksan. 2019. Kontestasi Merebut Kebenaran Islam di Indonesia: Dari Berislam Secara Teologis Menuju Berislam Secara Humanis. Yogyakarta: IRCiSoD. 